\title{
Relational Learning With Indigenous Communities: Elders' and Students' Perspectives on Reconciling Indigenous Service-Learning
}

\section{Andrea Kennedy}

Katharine McGowan

Gabrielle Lindstrom

Christian Cook

Yasmin Dean

James Stauch

Mount Royal University, Canada

Cheryl Barnabe

University of Calgary, Canada

\section{Stephen Price}

Mount Royal University, Canada

with

\section{Elder Roy Bear Chief}

Blackfoot Siksika Nation

\section{Grandmother Doreen Spence}

Saddle Lake Cree Nation

\section{Kupuna Francine Dudoit Tagupa}

Waikiki Health, Hawaii, USA

\section{Recommended Citation:}

Kennedy, A., McGowan, K., Lindstrom, G., Cook, C., Dean, Y., Stauch, J., Barnabe, C., \& Price, S. (with Bear Chief, R., Spence, D., \& Tagupa, K. F. D.). (2020). Relational learning with Indigenous communities: Elders' and students' perspectives on reconciling indigenous service-learning. International Journal of Research on Service-Learning and Community Engagement, 8(1), Article 2. 


\title{
Relational Learning With Indigenous Communities: Elders' and Students' Perspectives on Reconciling Indigenous Service-Learning
}

\author{
Andrea Kennedy \\ Katharine McGowan \\ Gabrielle Lindstrom \\ Christian Cook \\ Yasmin Dean \\ James Stauch \\ Mount Royal University, Canada \\ Cheryl Barnabe \\ University of Calgary, Canada \\ Stephen Price \\ Mount Royal University, Canada \\ with \\ Elder Roy Bear Chief \\ Blackfoot Siksika Nation \\ Grandmother Doreen Spence \\ Saddle Lake Cree Nation \\ Kupuna Francine Dudoit Tagupa \\ Waikiki Health, Hawaii, USA
}

This study counterbalances Western-derived evidence by describing Elders' and students' perspectives of Indigenous service-learning through Indigenous research methodology. Data collection took place in a midsize Canadian university after an Indigenous service-learning public networking forum. The purposive sample consisted of three Indigenous elders and five Indigenous students. Immediately following the event, Elders participated in a focus group, and then students completed a survey. Qualitative themes were interpreted using conversational method and relational analysis. Elders called for the replacement of the term service-learning, re-rooting of the term Indigenous, and respect for the Elders' roles and knowledges. Interconnected themes by Elders and students signalled a necessary shift from service-learning to relational learning. Such connections reveal the core purpose of relational learning with Indigenous communities as maintaining good relations through humility, respect, honesty, and reciprocity while responding to the interconnected priorities of the land, traditional ways, Elders, and common language. Findings signal decolonizing opportunities for relational learning with Indigenous communities.

Keywords: conversational method, decolonization, Elders, Indigenous knowledge, relational learning 


\section{Aprendizaje relacional con comunidades indígenas: Perspectivas de aprendices y Maestros ancianos ['Elders'] en la reconciliación del aprendizaje-servicio indígena}

Este estudio contrarresta la evidencia derivada de occidente al describir las perspectivas de Maestros ancianos [llamados "Elders" entre los pueblos indígenas norteamericanos] y aprendices sobre el aprendizaje-servicio indígena a través de la metodología de investigación indígena. La recolección de datos se llevó a cabo en una universidad canadiense de tamaño mediano tras la celebración de un foro de networking público de aprendizaje-servicio para indígenas. La muestra útil consistió en tres Maestros y cinco aprendices indígenas. Inmediatamente después del evento, los Maestros participaron en un focus group de una hora y los estudiantes completaron una encuesta. Los temas cualitativos se interpretaron utilizando el método conversacional y el análisis relacional. Los Maestros pidieron la sustitución del término aprendizaje-servicio, la recuperación del término indígena y el respeto hacia los conocimientos y el rol de los Maestros. Las conexiones entre los temas discutidos por Maestros y estudiantes demostraron la necesidad de un cambio del aprendizaje-servicio al aprendizaje relacional. Dichas conexiones revelan el propósito central del aprendizaje relacional con las comunidades indígenas, como mantener buenas relaciones a través de la humildad, el respeto, la honestidad y la reciprocidad mientras se responde a las prioridades interconectadas de la tierra, las formas tradicionales, los Maestros y el lenguaje común. Los hallazgos señalan oportunidades de descolonización para el aprendizaje relacional con comunidades indígenas.

Palabras clave: método conversacional, descolonización, Maestros, conocimiento indígena, aprendizaje relacional

Editors' Note: Translation by Beatriz Calvo-Peña Department of English and Foreign Languages Barry University, USA

Whereas service-learning and community engagement are grounded in reciprocity and mutually beneficial relationships, this has been established mainly through colonial approaches (Kenny \& Gallagher, 2002). We are called to right relations with Indigenous Peoples (Truth and Reconciliation Commission of Canada, 2015; United Nations, 2007) through actions that disrupt the harmful roots of colonial power. Decolonization in higher education is an uncomfortable process that includes critically reexamining practices, structures, and systems that may be implicitly or explicitly maintain Eurocentric domination (Battiste, 2013; Stein, 2017). This study may evoke unease as it exposes the colonial roots of service-learning, seeking to deconstruct Indigenous service-learning from the perspective of Indigenous Elders and students. We hope the study findings will support actions to decolonize institutional priorities to advance respectful engagement and co-learning with Indigenous communities.

\section{Positionality and Elders Consultation}

The research team is of Blackfoot, Métis, and Settler ancestry, representing First Peoples and guests on the traditional lands where the study took place. All three Elders are highly respected advocates for Indigenous community wellbeing in their traditional territories. Elder Roy Bear Chief (Blackfoot Siksika Nation) is a university Elder in residence, retired social worker and nurse, and previous Tribal Council representative. Grandmother Doreen Spence (Saddle Lake Cree Nation) is a traditional healer, retired nurse, and global Indigenous human rights advocate. Kupuna Francine Dudoit Tagupa (Hawaii) is Director of Native Hawaiian Healing at Waikiki Health; a traditional healer, nurse, and political activist. This research was informed by Indigenous knowledges shared by the Elders from their respective traditions. Blackfoot teachings of Kimma Pi Pitsin (kindness - compassion), Cree teachings of Kisewatisiwin (kindness) and Hawaiian teachings of Aloha (love) are aligned and foundational to this research purpose and process. This stance is a form of convergence (Ray, 2012) of Western academic efforts (such as this study) interconnected with traditional Indigenous knowledges from distinct nations "guide the ethos of the approach" (p. 91). 
Several members of the research team (Indigenous and non-Indigenous) have learned with these Elders for many years, with a focus on respectful engagement by the academy with Indigenous communities to advance wellbeing. The principal investigator is hanai (traditionally adopted) by Francine; sharing knowledge through generations is part of the responsibility and privilege of kinship. Respectful and trusted relationships among the Elders and the research team were key to the success of planning and conducting this study. Supported by Elders, the research team engaged in the sometimesuncomfortable critical reflection to examine our academic positions, processes, and knowledge development with respect to Indigenous ways of being, knowing, and doing. While westernized knowledge claims objectivity and cautions against bias, Indigenous worldview is founded on subjective inter-relational understanding and accountability (Bourque Bearskin, 2011; Kovach, 2010). Rather than a polarizing approach, this study is based on relationships, respectful engagement, and convergence of Western and Indigenous knowledges to broaden perspectives in the academy (Deloria et al., 1999; Ray, 2012).

Elders were offered tobacco as protocol and they provided guidance on the complete research process. They helped plan the Indigenous service-learning, public networking forum, emphasizing how knowledge comes from our relationship with the land and community. Elders requested that data collection begin with a one-hour debrief session after the event to review and reflect with one another on how Indigenous service-learning is understood and how we may move forward in a good way. They requested that their names and narrative as study participants be published and agreed to meet with the research team to clarify concepts and provide ongoing guidance. Elders recommended that students be part of this study as the next generation of knowledge holders and approved for students to be guest listeners in their debrief. They did not wish to be acknowledged as 'researchers' as they felt this title did not fully reflect their contribution as Elders. As a decolonial effort, this study was developed and conducted with an authentic respect for Elders whose Indigenous Knowledge Systems are often marginalized in the academy and society (Battiste, 2005).

\section{Literature Review}

\section{History}

Service-learning is a term that originated in American college programs in the late 1960s for students to gain academic credit and/or payment for community project work (Sigmon, 1979). Foundations of service-learning are rooted in Dewey's theories of democracy, citizenship, and experiential learning (Dewey, 1938; Giles \& Eyler, 1994) and mobilized through volunteerism and social activism (Kenny \& Gallagher, 2002). However, Dewey (1938) noted how education and experience are not equivalent and cautioned that "an experience may be such as to engender callousness; it may produce lack of sensitivity and responsiveness" (p. 25). Academic institutional values determine the public purpose of servicelearning and may reflect a combination of moral, religious, political, civic, and educational goals. Over the decades, service-learning has developed as a widely adopted pedagogical approach for transformative learning and social justice (Chambers, 2009; Clayton et al., 2010; Taylor et al., 2015). However, such institutional aims may be confounded within an unexamined colonial system that marginalizes meaningful contribution of Indigenous knowledges and rewards ongoing domination of westernized ways of being, knowing, and doing (Battiste, 2013; Hernandez, 2016; Santiago-Oritz, 2019; Stoecker, 2016). Thus, it is important to consider how service-learning may be problematic with Indigenous communities as "programs unwittingly perpetuate the marginalization of Indigenous Peoples and exhibit paternalistic attitudes during community engagement" (Milleret al., 2018, pp. 30-31).

\section{Indigenous Service-Learning}

Indigenous service-learning recently emerged in the literature (McNally, 2004), and is understood as relational experiential education through reflective process, reciprocal partnerships, and respectful 
engagement with Indigenous knowledge systems to advance Indigenous community-driven goals (Spenceet al., 2018). Distinct Indigenous knowledge systems are transmitted by Indigenous Peoples over generations and respected for their contributions over millennia to advance holism, interrelatedness, sustainability, and wellness (Bolea, 2012). However, colonial systems dismiss Indigenous knowledges and continue to oppress Indigenous Peoples with pervasive and harmful myths of being "backward and as passive recipients of European knowledge" (Battiste, 2005, p. 2). To counter such harm, decolonizing requires respectful engagement with Indigenous communities and Elders as valued knowledge holders with protected human rights (Bolea, 2012; Thibeault, 2019). Engaging in this ethical space of servicelearning requires cultural humility to support culturally safe interactions (First Nations Health Authority, 2020; Curtis et al., 2019).

Canadian scholars Kajner, Fletcher, and Makokis (2012) endorse a "head and heart approach to community-engaged scholarship ... [that] provides access to an ethical space where multiple worldviews are recognized and where the importance of relational accountability becomes evident" (p. 257). A phenomenological study by Pratt and Danyluk (2017) on service-learning experiences of students teaching in Indigenous communities revealed the importance of critical reflection to support decolonization efforts and reciprocity for transformative learning (Mezirow \& Associates, 2000). Best practices in community-service learning with Indigenous communities call for attention to the key elements of respect, relevance, reciprocity, and responsibility (Kirkness \& Barnhardt, 2001).

Miller and others (2018) proposed research with a mixed-methods design to challenge the status quo and explore how inclusion of Indigenous voices impact Ibero-American international service-learning programs based on Sigmon's (1979) foundational principles: those being served have control; those served become better able to serve themselves; and those serving are learners who shape their own outcomes (p. 31). A team of Australian scholars have published a series of compelling original research on Indigenous service-learning. Bartleet et al. (2014) engaged with students and Indigenous knowledge holders to develop a framework for reconciliation through arts-based co-learning with Indigenous communities. Concerns of legitimacy and institutionalizing service-learning led to further research revealing complex challenges, interactions, and the need for organizational commitment by higher education in relationship with Indigenous communities (Bennett et al., 2016). This was followed by a multisite study with Indigenous Knowledge holders and students, leading to a framework for servicelearning with First Peoples (Bartleet et al., 2019). "Respectful and mutually beneficial partnerships" (p. 27) amongst students, faculty, and community partners were framed through connection with land, Elders past and present, critical reflection, and respecting Indigenous culture.

A decolonizing lens helps us to critically appraise whether service-learning is centered with Indigenous community ways of being, knowing, and doing, or instead "inevitably centres colonial logic" (Siumet al., 2012, p. IV). While the term service-learning is of concern, further prefixing 'Indigenous' to existing theory may perpetuate ignorance of privilege that lacks respect for the nuances and unique historical and social context of Indigenous Peoples and communities (Crowshoe et al., 2019; Mitchell, 2013; Mitchell et al., 2012). It is thereby fitting to consider decolonizing social justice approaches such as antiracism, anticolonialism, and critical theories as the basis of Indigenous service-learning.

\section{Decolonizing Service-Learning}

Decolonizing efforts in service-learning may be enacted through critical reflection and "center[ing] Indigenous ways of knowing, learning, and teaching [through] anti-racist and anti-imperialist pedagogies" (Dillonet al., 2019, p. 195). Social justice is the key aim of critical service-learning pedagogy, with key elements including attention to social change, the redistribution of power, and the development of authentic relationships (Mitchell, 2013). To engage in positive change, the academy needs to engage in self-implicated critique (Andreotti, 2015) and acknowledge the existence of colonial white privilege and supremacy. Critical service-learning requires corresponding social justice "strategies to interrupt whiteness in service learning and provide more educative experiences for all students" (Mitchell et al., 2012, p. 623). These aims may prove difficult if the academy is unwilling to critically focus on the 
structural issues at the root of service-learning (Pratt \& Danyluk, 2017). While critical service-learning may be seen as "revolutionary pedagogy" (Porfilo \& Hickman, 2011), there is inherent paradox in this approach (Ahenakew, 2017), given that service-learning has roots in colonial institutional values and may not be centered with Indigenous community ways.

We must acknowledge the distinct colonial oppression of Indigenous Peoples through attempted erasure and consider how broad and pervasive societal structures continue to reinforce and reward colonialism within higher education (Tuck \& Yang, 2012). Santiago-Ortiz (2019) has called for an anticolonial stance in service-learning by acknowledging colonialism within and beyond the academy, countering dominant discourse, and shifting community-university partnerships. Challenging Western epistemological dominance in service-learning is an overdue "radical reform" shift to address "unequal relations of knowledge production [that] result in severely uneven distribution of resources" (Andreotti et al., 2015, p. 26). Reconciling Indigenous ways of being, knowing, and doing in learning with communities presents an important opportunity to uphold the United Nations Declaration on the Rights of Indigenous Peoples (2007). We must consider if and how Indigenous service-learning approaches are decolonized so that the academy is not causing further harm and may optimize reconciliation with Indigenous communities.

There are tensions between westernized academic processes, such as service-learning, that are guided by Indigenous ways (Ahenakew, 2017). Such work requires convergence of Western and Indigenous knowledges (Ray, 2012). Thus, it was not surprising that all Indigenous service-learning literature sources reviewed in this summary integrated Western and Indigenous knowledge. Ermine's (2007) lessons on engaging in ethical space and Mi'kmaw Elder Albert Marshall's (2018) teachings of Etuaptmumk (twoeyed seeing) may help us understand how to engage with Western and Indigenous knowledges that are distinctly woven together for the benefit of all (Marshall et al., 2015; Thibeault, 2019). This is not a mere blending of knowledges, but rather a respectful convergence (Ray, 2012) to engage with disparate worldviews (Ermine, 2007, p. 193). Such engagement requires understanding of the strengths, history, and cultural context of Indigenous knowledges and Peoples held in tension with entrenched colonial power and structures (Ahenakew, 2017). Understanding leads to opportunity for decolonizing servicelearning that disrupts colonial dominance with actions grounded in respect, relevance, reciprocity, and responsibility (Kirkness \& Barnhardt, 2001). This creates space for learning with "love as a radical grounding force" (Boveda \& Bhattacharya, 2019, p. 4) that is aligned with traditional Indigenous teachings (Spence et al., 2018). From this decolonizing stance, we are better suited to critically understand how to engage in reconciliation as learners with Indigenous communities.

\section{Research Question}

While evidence supports how to engage in Indigenous service-learning, original research was not located on the indicators of Indigenous service-learning. Do we understand the essence of Indigenous servicelearning? We need to step back and consider the elements of this widely adopted approach and ask Indigenous knowledge holders themselves to explore and describe the fit of Indigenous service-learning. From a decolonizing stance in the academy, we recognize Indigenous Elders as valued knowledge holders and Indigenous students as the respected next generation to carry this knowledge. This provides the basis for our research purpose and question: What is Indigenous service-learning from the perspective of Elders and students?

\section{Method}

This qualitative study describes how Elders and students understand Indigenous service-learning through the Indigenous research methodology of relationality (Deloria et al., 1999) and conversational method (Kovach, 2010). This study is grounded in Indigenous ways with convergence of westernized research processes (Ray, 2012). 


\section{Setting and Participants}

This study took place in a midsize Canadian university after a public networking forum on Indigenous service-learning. Participants were selected through purposive sampling of Indigenous Elders $(\mathrm{n}=3)$ who co-led the event and Indigenous students $(n=5)$ who volunteered at the event. Participant recruitment was by email with a consent package consistent with OCAPTM (ownership, control, access, and possession) principles (Bourque Bearskin, 2014; First Nations Centre, 2005).

\section{Data Collection}

Data collection occurred in two phases immediately after the public event in an adjacent room. Questions were presented in a semi-structured focus group interview format with Elders, and a structured written survey format with students:

1. What is the most important and resonating point raised today?

2. What is Indigenous service-learning as compared with the draft operational definition? ("Indigenous service-learning is relational experiential education through reflective process, reciprocal partnerships and respectful engagement with Indigenous knowledges to advance Indigenous community-driven goals.")

3. What are key indicators of Indigenous service-learning?

4. What are key challenges/gaps to implementing Indigenous service-learning?

5. What are key opportunities/resources to implementing Indigenous service-learning?

6. What is the role of Elders in Indigenous service-learning?

7. Other thoughts/comments.

Elders' Focus Group. The key purpose of this focus group was to generate knowledge and understanding of Indigenous service-learning from the perspective of Elders. A one-hour debrief/focus group with three Elders was facilitated by the principal investigator, with five student volunteers, who were asked to only speak if invited by an Elder to do so. Two members of the research team were present to observe and write field notes. This debrief was audio-recorded and transcribed, with only Elders' voices identified; other voices were reported as an aggregate. Elders validated the debrief transcript.

Student Survey. The key purpose of this survey was to generate knowledge and understanding of Indigenous service-learning from the perspective of students. A paper survey was completed by seven students. This survey had one closed-ended and eight open-ended questions and took 20-30 minutes to complete.

\section{Data Analysis}

Qualitative analysis of transcribed audio-recording focus group narrative and survey comments was conducted through manual coding of data by six researchers. Elder Roy Bear Chief helped the research team in our ongoing decolonizing efforts and shared guidance on creating understanding as follows:

Consider the internal workings of the academy and the silos going up. This needs to be taken down and replenished with the culture and evolving within non-Indigenous ways and systems. It fails if we are not truly sharing and collaborating with understanding Nisto [me]-Kisto [you]-Kistoonon [all of us together]. Are we being authentic in Indigenization and decolonization of this research? There is relevance in Indigenous ways, but is there fear of including Indigenous ways? We are not a threat. This is about helping each other in reconciliation. The responsibility of a researcher is to look-listen-learn as a lifelong journey. Hear the stories, reflect, and be in protocol. You have responsibility to the spiritual connection of the whole story - mind, body, emotion, and spirit. This is the lens for responding to the vibrations of Anitopisi [story of relationships as spider web] at the core of our essence as helpers. (Personal communication, February 4, 2020)

Indigenous research methods of relational analysis (Deloria et al., 1999) and conversational method (Kovach, 2010) were used to address the incongruence of westernized reduction and separation of 
Indigenous concepts that are whole and related. Relational analysis was used to describe connections among knowledges, perspectives, time, and places in the Elders' focus group narrative and the students' written survey comments. The Elders' focus group narrative was also analyzed using conversational method in Indigenous research to bring forward condensed stories (Kovach, 2010). Key themes represent whole stories from an Indigenous paradigm and resist a westernized hierarchy of sub-concepts that is often employed in thematic analysis (Nowell et al.2017). This process was conducted by mapping connections within and between groups. This approach is aligned with the positionality of this research process from Indigenous worldviews that respects the interconnection of Elders' and students' stories.

\section{Ethics}

This study was approved through an institutional research ethics review board. Confidentiality could not be guaranteed due to the nature of the public networking event and focus group. This was addressed in the consent process and before the debrief as "ground rules" to respect the privacy of fellow participants. Elders consented to being identified with their contribution to the research process. Each Elder has coownership of the data, with the freedom to use any piece of the textual data for personal or professional purposes. This supports the ethical practices of working with Indigenous Peoples and is also sanctioned by the First Nations Information Governance Committee as the OCAP principles enable selfdetermination over all research concerning First Nations (First Nations Centre, 2005). Elders are invited to provide input and participate as co-authors for all presentations and publications, as noted in the criteria presented by the International Committee of Medical Journal Editors (2019).

\section{Results and Recommendations}

Findings are shared as results and recommendations, honoring the interconnection of Indigenous ways of being, knowing, and doing. While written findings are presented in this report to enhance academic knowledge sharing, it is of great importance that Elders provide ongoing guidance to the research team on various knowledge mobilization strategies aligned with local Indigenous community ways. How Elders and students understand Indigenous service-learning is revealed through their oral and written stories with clear recommendations for action.

\section{Elders' Stories}

Elders validated their teachings from the focus group debrief as condensed stories (Kovach, 2010). These teachings are both findings and recommendations for action as described below.

Elder Roy Bear Chief: Replace the term service-learning. There is serious concern about the term Indigenous service-learning as a westernized and misunderstood term because it does not respect Indigenous ways. This is highly problematic because the lack of relevance will prevent honest partnerships between the university and Indigenous communities. The university needs to use common language and understanding that is humbly, honestly, and respectfully shared by local Indigenous community ways of life and Elders' wisdom. Service-learning is about the university; helping and colearning is about relationships with Indigenous communities.

Kupuna Francine Dudoit Tagupa: Re-root the term Indigenous. The term Indigenous is vague when out of context, perpetuating disregard of Indigenous Peoples by Western society; this term must be re-rooted in the land and local community ways of being, knowing, and doing. In this partnership, the university needs to act "for the good of the people" and honour the Indigenous community's gain/benefit as central "with a good heart." Relationships and trust take time and must be cultivated with humble respect of the local knowledge and protocol of the community.

Grandmother Doreen Spence: Respect the Elders' roles and knowledges. Elders are essential to setting the direction for community engagement; yet they are often missing in essential roles within the higher education system. The university needs to practice cultural humility when working with Elders and Indigenous communities so that interactions are culturally safe. This requires respect for worldviews that 
are about relationships with all beings and the environment. Elders are necessary to support and validate this partnership process because "you can buy education, but you can't buy wisdom." The university needs an Elders Council that represents the diverse Indigenous community where the university is situated.

\section{Elders' and Students' Stories as Interconnected Themes}

Elders further validated connections between their stories (Deloria et al., 1999). Students' narratives evolved in a constructivist manner with each response, and their written feedback was interpreted as a whole rather than segmented responses to individual survey questions (Deloria et al., 1999). Connections were mapped within and between groups to describe how Indigenous Elders and students deconstructed Indigenous service-learning and reoriented understanding from an Indigenous worldview.

Elders' debrief and students' written feedback were interpreted as a whole with relational analysis (Deloria et al., 1999) of themes as interconnected priorities. We respect the non-hierarchical relationality of Elders' and students' understanding of Indigenous service-learning. Through relational epistemology, information is received as perceptions and understanding is mediated through maturity (Deloria et al., 1999). Elders see themselves broadly in relation to community, whereas students focused their perspective as learners. The maturity of Elders shines light on their role in complex community engagement. This further supports the importance of Elders within the university to formally guide engagement with Indigenous communities. Correspondingly, students' fresh perspectives on their learning experiences and respect for self-knowledge are foundational to developing expertise in relational learning spaces (Deloria et al., 1999). This stance reinforces how the students' personal learning journey has value; students have the inherent capacity to effectively engage as co-learners with Peoples and places. The interplay of Elders' and students' perspectives helps us to appreciate the dimensions of interconnected priorities within generations (see Figure 1).

Relationships are mapped based on traditional Blackfoot teachings gifted by Elder Roy Bear Chief: The Creator instructed Anitopisi to wrap the world, with the people in it, in his web and let them down to the lower world. After the people were lowered from the upper world (spoomootsi), Anitopisi explained to them that the web would remain with them so that the Creator would know when to help them. When there was trouble or an emergency, one string of the web would vibrate and signal the Creator to come to help. The people were told to pattern their lives after the web so they can stay close together and help each other whenever there is a problem, a vibration on the web. The whole concept behind the spider web is well adapted to the idea of working together to reach common goals. (Bear Chief \& Spence, 2019)

These teachings bring forward the interconnected web of relationality and show how key themes raised by Elders and students create a vibration in the web to alert important priorities as recommendations. This signals a necessary shift from Indigenous service-learning to relational learning as an active and dynamic process of co-creating knowledge through critical self-awareness while striving for meaningful contribution with others. This web helps us understand the core purpose of relational learning with local Indigenous communities as maintaining good relations through humility, respect, honesty, and reciprocity in response to the following interconnected priorities (see Figure 2):

1. The Land-local context where knowledge is held

2. Traditional Ways - collectivist, co-learning and helping

3. Common Language - clear and shared communication

4. Elders - guiding community engagement and relational learning 


\section{Figure 1}

Interconnected Priorities of Elders and Students

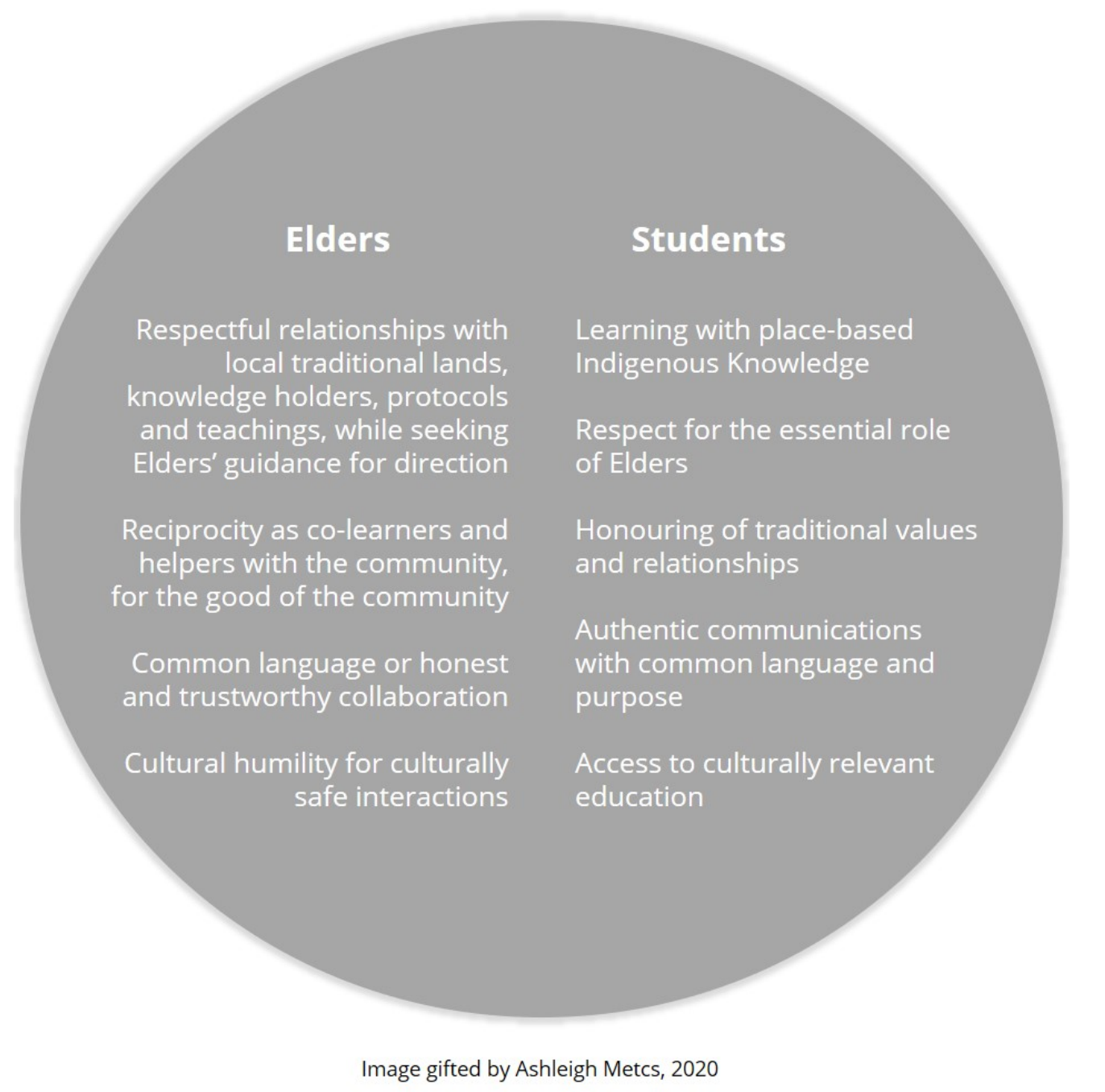

Findings bring us full circle to recommendations shared by the Elders in their condensed stories. We are thereby reminded of three key lessons: Replace the term Indigenous service-learning with common language; re-root the term Indigenous with local traditional Knowledges as the source and respect for the Elders' roles; and knowledges through meaningful engagement. Thus, Indigenous service-learning is reimagined and reoriented centrally through Indigenous ways as relational learning with local Indigenous communities with the land, traditional ways and Elders through common language that is grounded in humility, respect, honesty, and reciprocity.

\section{Strengths, Limitations, and Lessons Learned}

Study strengths, limitations, and lessons learned are considered as we reflect on the research process, which could inform future action. Strengths include constructing meaningful relationships with Elders and engagement in an Indigenous research methods study with Indigenous Peoples led by a reflexive team of Indigenous and non-Indigenous researchers. From a westernized perspective, limitations include generalizability, given the small sample size of the qualitative study; from an Indigenous perspective, 
limitations include confined written student survey responses, rather than oral storytelling, and lack of student validation for survey data analysis.

\section{Figure 2}

\section{Relational Learning with Indigenous Communities}

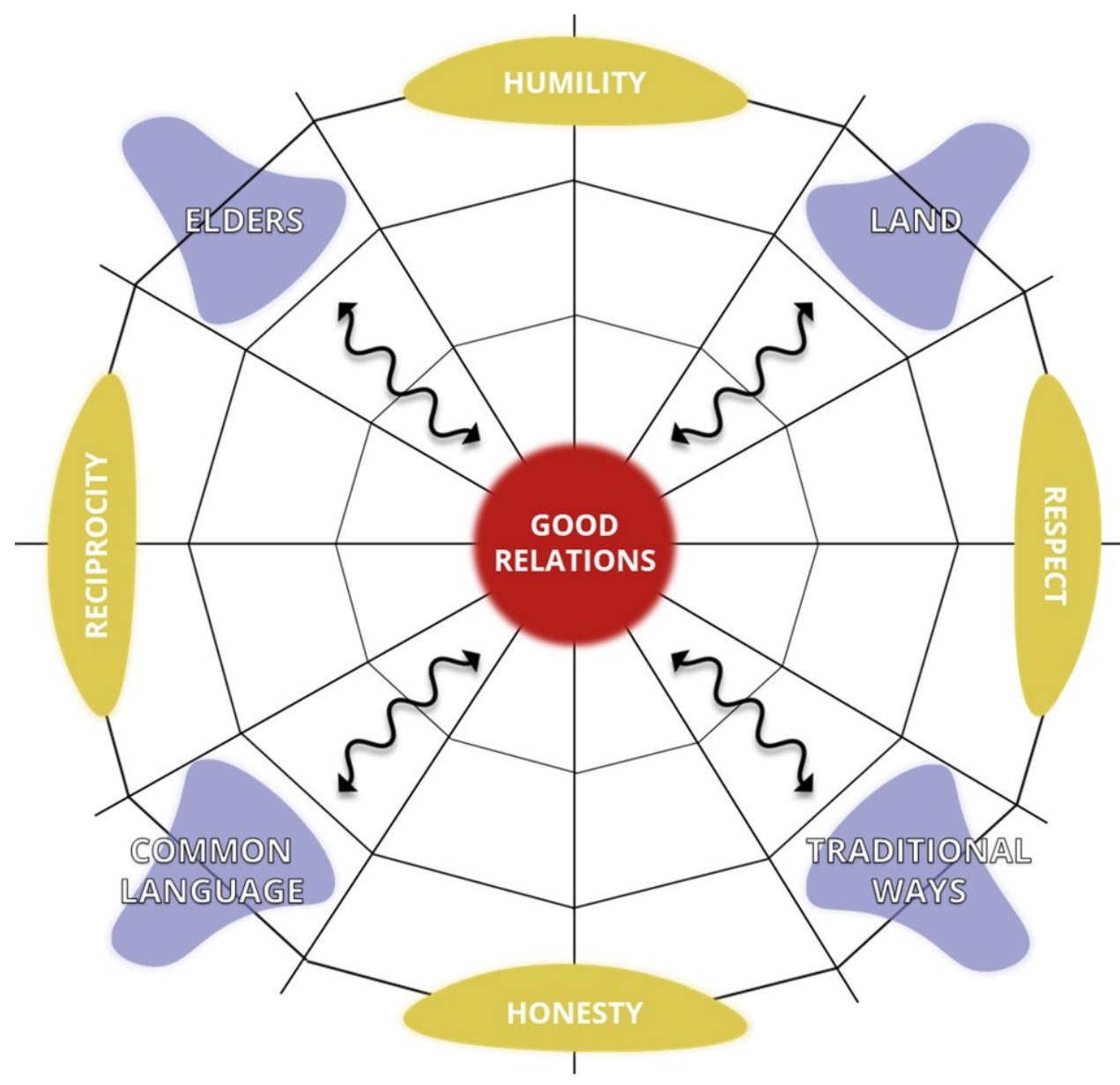

Image gifted by Ashleigh Metcs, 2020

Given the highly reflexive approach throughout this study, many lessons were learned, with ongoing reflection to inform future work. The original study protocol used thematic analysis; however, given the critical reflection and inherent relational learning experienced by the research team, this approach was shifted to Indigenous research methods so as to authentically respect the worldview and contributions of Indigenous Elders and students. This change was critical because, without a relational epistemology (Deloria et al., 1999), this research would have risked further entrenching westernized ways, rather than honoring meaningful space for Indigenous knowledge.

Furthermore, while Indigenous research methods may include tools such as surveys (Drawsonet al., 2017), westernized academic control over the students' contribution was maintained through the selected data collection and analysis methods. An invitation for Indigenous students to participate in the study design and to validate findings would have been a better approach for rebalancing power and honoring Indigenous self-determination (Drawson et al., 2017). Such lessons are powerful reminders that 
decolonization is an evolving, self-implicated process that requires ongoing critical reflection and corresponding action.

\section{Discussion}

Study findings call for positive change to reimagine and reorient Indigenous service-learning while challenging theoretical work that was originally published by research team members (Spence et al., 2018). In this previous work, research team member Kennedy, supported by Elders Grandmother Doreen and Kupuna Francine, focused on the positive experiences of learning with Indigenous communities and did not critically examine the entrenched colonialism of Indigenous service-learning. From an Indigenous learning approach, we have an ongoing opportunity to shift ways of being, knowing, and doing to authentically drive positive change in decolonizing efforts to realize relational learning with local indigenous communities. This is echoed globally, given how the research findings align with the Australian framework for service-learning with First Peoples (Bartleet et al., 2019) that is centered on "respectful and mutually beneficial partnerships" (p. 27) amongst students, faculty, and community partners through connection with land, Elders, ancestors, critical self-awareness, and respect for Indigenous culture. We agree with the Australian recommendations and hope further research will continue to uproot entrenched colonialism in higher education.

A simple yet powerful shift is realized in rejecting the term Indigenous service-learning and reorienting the process as relational learning with local Indigenous communities with common language. While service-learning may be supported through the congruence of Western and Indigenous knowledges, the language supporting this approach needs to respect relationships and the centrality of Indigenous ways. More so, we need to critically examine how Indigenous service-learning needs to move beyond attempts to merely graft Indigenous ways to westernized education (Tuck \& Yang, 2012; Mackinlay \& Barney, 2014). Our words convey intention as a foundation for action. Service-learning scholars may experience unease with this proposed change to established westernized scholarship, and we hope the source of this unease will be critically examined.

We also need to re-root local Indigenous Knowledge as central when co-learning with Indigenous communities. Local knowledge stemming from relationships with the land must be learned through experience guided by traditional knowledge holders. Indigenous communities need to define the nature of partnerships with higher education and consider how good relations may benefit their community. Quality relationships are supported by resolutions such as the United Nations Declaration on the Rights of Indigenous Peoples (2007). This fundamental positioning of local Indigenous knowledges and human rights is key; otherwise we continue to privilege westernized ways that "inevitably centres colonial logic" (Sium et al., 2012, p. IV).

In the academy, addressing power imbalances that ignore the essential role of Elders is long overdue. We are concerned when "Indigenous service-learning" courses are planned and implemented without meaningful involvement by Elders. There is risk of tokenism when Elders are asked to bless a project and yet are not consulted in its planning or delivery. Academics need to critically examine and create opportunities to engage Elders in the development of curriculum, pedagogy, evaluation, programs, and policy. We need to recognize Elders in leadership positions within the academy, so they may guide and influence engagement with Indigenous knowledges and communities.

\section{Conclusion}

In service-learning, the transfer of knowledge largely flows from the community to students, who are often seen as a "convenient volunteer pool" (Stoecker, 2016, p. 55). We need to question this transactional space as "services rendered" (Kupuna Francine Dudoit Tagupa) and reimagine an approach that fundamentally honors Indigenous ways. When reorienting learning with traditional teachings, students are valued for sharing their gifts in relationship with the Indigenous community, and their personal development is nurtured as a foundation for their professional expertise for the benefit of all 
(Deloria et al., 1999). The transactional state is disrupted by refocusing the shared responsibility and benefits of relational learning in Indigenous contexts. While this is both promising and reasonable, we are concerned that higher education will continue to overlook the well-known and pervasive harms of colonial power. This study presents an opportunity to address that structural fault by replacing the term Indigenous service-learning, re-rooting the term Indigenous, and respecting the Elders' roles and knowledges. We hope the study findings help us move forward together in a good way.

\section{References}

Ahenakew, C. R. (2017). Mapping and complicating conversations about Indigenous education. Diaspora, Indigenous and Minority Education: Studies of Migration, Integration, Equity, and Cultural Survival, 11(2), 80-91. https://doi.org/10.1080/15595692.2017.1278693

Andreotti, V. de O., Stein, S., Ahenakew, C., \& Hunt, D. (2015). Mapping interpretations of decolonization in the context of higher education. Decolonization: Indigeneity, Education \& Society, 4(1), 21-40.

Bartleet, B.-L., Bennett, D., Marsh, K., Power, A., Sunderland, N. (2014). Reconciliation and transformation through mutual learning: Outlining a framework for arts-based service learning with Indigenous communities in Australia. International Journal of Education and the Arts, 15(8), 1-23. http://www.ijea.org/v15n8/

Bartleet, B.-L., Bennett, D., Power, A., \& Sunderland, N. (2019). Service learning with First Peoples: A framework to support respectful and reciprocal learning. Intercultural Education, 30(1), 15-30. https://doi.org/10.1080/14675986.2018.1528526

Battiste, M. (2005). Indigenous knowledge: Foundations for First Nations. World Indigenous Nations Higher Education Consortium Journal, 1. https://journals.uvic.ca/index.php/winhec/issue/view/1406

Battiste, M. (2013). Decolonizing education: Nourishing the learning spirit. UBC Press.

Bear Chief, R., \& Spence, D. (2019). Reconciliation through Kimma Pi Pitsin: Kindness - compassion. https://www2.mtroyal.ca/ areil/kimma/story_html5.html

Bennett, D., Sunderland, N., Bartleet, B.-L., \& Power, A. (2016). Implementing and sustaining higher education service-learning initiatives: Revisiting Young et al.'s organizational tactics. Journal of Experiential Education, 39(2), 145-163. https://doi.org/10.1177/1053825916629987

Bolea, P. S. (2012). Cross-cultural service learning with Native Americans: Pedagogy for building cultural competence. Journal of Teaching in Social Work, 32(3), 284-299. https://doi.org/10.1080/08841233.2012.687684

Bourque Bearskin, R. L. (2011). A critical lens on culture in nursing practice. Nursing Ethics, 18(4), 548559. https://doi.org/10.1177/0969733011408048

Boveda, M., \& Bhattacharya, K. (2019). Love as de/colonial onto-epistemology: a post-oppositional approach to contextualized research ethics. The Urban Review, 51, 5-25. https://doi.org/10.1007/s11256-018-00493-z

Chambers, T. (2009). A continuum of approaches to service learning within Canadian postsecondary education. Canadian Journal of Higher Education, 39(2), 77-100.

Clayton, P. H., Bringle, R. G., Senor, B., Huq, J., \& Morrison, M. (2010). Differentiating and assessing relationships in service-learning and civic engagement: Exploitative, transactional, or transformational. Michigan Journal of Community Service Learning, 16(2), 5-22.

Crowshoe, L. L, Henderson, R., Jacklin, K., Calam, B., Walker, L., \& Green, M. E. (2019). Educating for equity care framework: Addressing social barriers of Indigenous patients with type 2 diabetes. Canadian Family Physician, 65(1), 25-33. https://www.cfp.ca/content/65/1/25

Curtis, E., Jones, R., Tipene-Leach, D., Walker, C., Loring, B., Paine, S.-J., \& Reid, P. (2019). Why cultural safety rather than cultural competency is required to achieve health equity: a literature review and recommended definition. International Journal for Equity in Health, 18(174), 1-17. https://doi.org/10.1186/s12939-019-1082-3 
Deloria, B., Foehner, K., \& Scinta, S. (Eds.). (1999). Spirit and reason: The Vine Deloria, Jr., reader. Fulcrum Publishing.

Dewey, J. (1938). Experience and education. Collier Books.

Dillon, W. T., BlueHorse-Skelton, J., \& Reitenauer, V. L. (2019). "Diversity," anti-racism, and decolonizing service learning in the capstone experience. The Journal of General Education, 67(3-4), 194-208. https://doi.org/10.5325/jgeneeduc.67.3-4.0194

Dillon, W. T., Bluehorse-Skelton, J., \& Reitenauer, V.L. (2019). "Diversity", anti-racism, and decolonizing service learning in the capstone experience. The Journal of General Education, 67(3-4), 194-208. https://doi.org/10.5325/jgeneeduc.67.3-4.0194

Drawson, A. S., Toombs, E., \& Mushquash, C. J. (2017). Indigenous research methods: A systematic review. The International Indigenous Policy Journal, 8(2). https://doi.org/10.18584/iipj.2017.8.2.5

Ermine, W. (2007). The ethical space of engagement. Indigenous Law Journal, 6(1), 193-203.

First Nations Centre. (2005). Ownership, control, access and possession (OCAP) or self-determination applied to research: A critical analysis of contemporary First Nations research and some options for First Nations communities. National Aboriginal Health Organization. https://ruor.uottawa.ca/bitstream/10393/30539/1/OCAP_Critical_Analysis_2005.pdf

First Nations Health Authority (2020). Cultural humility. https://www.fnha.ca/wellness/cultural-humility

Giles, D. E., Jr., \& Eyler, J. (1994). The theoretical roots of service-learning in John Dewey: Toward a theory of service-learning. Michigan Journal of Community Service Learning, 1(1), 77-85. http://hdl.handle.net/2027/spo.3239521.0001.109

Hernandez, K. (2016). Service and learning for whom? Toward a critical decolonizing bicultural service learning pedagogy [Unpublished doctoral dissertation]. Loyola Marymount University.

International Committee of Medical Journal Editors. (2019). Recommendations for the conduct, reporting, editing, and publication of scholarly work in medical journals. http://www.icmje.org/icmje-recommendations.pdf

Kajner, T., Fletcher, F., \& Makokis, P. (2012). Balancing head and heart: The importance of relational accountability in community-university partnerships. Innovative Higher Education, 37(4), 257-270. https://doi.org/10.1007/s10755-011-9206-8

Kenny, M. E., \& Gallagher, L. A. (2002). Service-learning: A history of systems. In M. E. Kenny, L. A. K. Simon, K. Kiley-Brabeck, \& R. M. Lerner (Eds.), Learning to serve: Promoting civil society through service learning (pp. 15-29). Springer.

Kirkness, V. J., \& Barnhardt, R. (2001). First Nations and higher education: The four r's - Respect, relevance, reciprocity, responsibility. Journal of American Indian Education, 30(3), 1-15.

Kovach, M. (2010). Conversation method in Indigenous research. First Peoples Child \& Family Review, 5(1), 40-48. https://doi.org/10.7202/1069060ar

Marshall, A. (2018, June). Learning together by learning to listen to each other. EdCan Network. https://www.edcan.ca/articles/learning-together-learning-listen/

Marshall, M., Marshall, A., \& Bartlett, C. (2015). Two-eyed seeing in medicine. In M. Greenwood, S. de Leeuw, \& C. Reading (Eds.), Determinants of Indigenous peoples' health in Canada: Beyond the social (pp. 16-24). Canadian Scholars' Press.

Mackinlay, E. \& Barney, K. (2014). Unknown and unknowing possibilities: Transformative learning, social justice, and decolonising pedagogy in Indigenous Australian studies. Journal of Transformative Education, 12(1), 54-73. https://doi.org/10.1177/1541344614541170

McNally, M. D. (2004). Indigenous pedagogy in the classroom: A service learning model for discussion. American Indian Quarterly, 28(3/4), 604-617. https://doi.org/10.1353/aiq.2004.0102

Mezirow, J., \& Associates (Eds.). (2000). Learning as transformation: Critical perspectives on a theory in progress. Jossey-Bass.

Miller, C. D., Kennedy, P., Cusiyupanqui, Y., Cusiyupanqui., J. C., \& Salzarulo, A. (2018). Putting the pen in their hands: Using Indigenous knowledge and perspectives to re-map global education and strengthen international service learning. Journal of Higher Education Theory and Practice, 18(5), $30-33$. 
Mitchell, T. D. (2013). Critical service-learning as a philosophy for deepening community engagement. In A. Hoy \& M. Johnson (Eds), Deepening community engagement in higher education: Forging new pathways (pp. 263-269). Palgrave Macmillan.

Mitchell, T. D., Donahue, D. M., \& Young-Law, C. (2012). Service learning as a pedagogy of whiteness. Equity \& Excellence in Education, 45(4), 621-629. : https://doi.org/10.1080/10665684.2012.715534

Nowell, L. S., Norris, J. M., White, D. E. \& Moules, N. J. (2017). Thematic analysis: Striving to meet the trustworthiness criteria. International Journal of Qualitative Methods, 16(1). https://doi.org/10.1177/1609406917733847

Porfilo, B. J. \& Hickman, H. (Eds.). (2011). Critical service-learning as revolutionary pedagogy: A project of student agency in action. Information Age Publishing.

Pratt, Y. P., \& Danyluk, P. J. (2017). Learning what schooling left out: Making an Indigenous case for critical service-learning and reconciliatory pedagogy within teacher education. Canadian Journal of Education, 40(1). https://journals.sfu.ca/cje/index.php/cje-rce/issue/view/113

Ray, L.W. G. (2012). Deciphering the "Indigenous" in Indigenous methodologies. AlterNative: An International Journal of Indigenous Peoples, 8(1), 85-98. https://doi.org/10.1177/117718011200800107

Santiago-Ortiz, J. D. A. (2019). From critical to decolonizing service-learning: Limits and possibilities of social justice-based approaches to community service-learning. Michigan Journal of Community Service Learning, 25(1), 43-54.

Sigmon, R. L. (1979). Service-learning: Three principles. Synergist, 8(1), 9-11.

Sium, A., Desai, C., \& Ritskes. E. (2012). Towards the 'tangible unknown': Decolonization and the Indigenous future. Decolonization: Indigeneity, Education \& Society, 1(1), I-XIII. https://jps.library.utoronto.ca/index.php/des/article/view/18638

Spence, D., Dudoit Tagupa, F., Kennedy, A. P., Semple, L., Cardinal, S., Jones, R., \& Scott, M. (2018). Localto-global indigenous health in service-learning: Collaboration with child, family, and community. In D. E. Lund (Ed.), The Wiley international handbook of service-learning for social justice (pp. 145-170). Wiley. https://doi.org/10.1002/9781119144397.ch6

Stein, S. (2017, December 5). So you want to decolonize higher education? Necessary conversations for non-Indigenous people. Medium. https://medium.com/@educationotherwise/https-medium-comeducationotherwise-so-you-want-to-decolonize-higher-education-4a7370d64955

Stoecker, R. (2016). Liberating service learning and the rest of higher education civic engagement. Temple University Press.

Taylor, A., Butterwick, S. J., Raykov, M., Glick, S., Peikazadi, N., \& Mehrabi, S. (2015). Communityservice learning in Canadian higher education. The University of British Columbia. https://open.library.ubc.ca/cIRcle/collections/facultyresearchandpublications/52383/items/1.0226035

Thibeault, D. (2019). Understanding Indigenous culture through service learning and cultural immersion, Journal of Social Work Education, 55(3), 476-488. https://doi.org/10.1080/10437797.2019.1593901

Truth and Reconciliation Commission of Canada. (2015). Truth and Reconciliation Commission of Canada: Calls to action. http://trc.ca/assets/pdf/Calls to_Action_English2.pdf

Tuck, E., \& Yang, K. W. (2012). Decolonization is not a metaphor. Decolonization: Indigeneity, Education \& Society, 1(1), 1-40. http://www.decolonization.org/index.php/des/article/view/18630/15554

United Nations. (2007). United Nations declaration on the rights of Indigenous peoples. https://www.un.org/development/desa/indigenouspeoples/wpcontent/uploads/sites/19/2018/11/UNDRIP_E_web.pdf 


\section{Author Note}

This work is dedicated with respect and gratitude to Elder Roy Bear Chief (Siksika Nation), Grandmother Doreen Spence (Saddle Lake Cree Nation), and Kupuna Francine Dudoit Tagupa (Hawaii). We have no known conflict of interest to disclose. Funding for this research project was generously provided by the Mount Royal University Faculty of Health, Community and Education Innovation Fund and the University of Calgary, Alberta Indigenous Mentorship in Health Innovation (AIM-HI) Network.

\section{About the Authors}

Andrea Kennedy is an associate professor in the School of Nursing and Midwifery-Faculty of Health, Community and Education - at Mount Royal University (Calgary, Alberta, Canada).

Katharine McGowan is an assistant professor in the Bissett School of Business, at Mount Royal University.

Gabrielle Lindstrom is an assistant professor of Indigenous Studies in the Faculty of Arts at Mount Royal University.

Christian Cook is an associate professor in the Bissett School of Business at Mount Royal University.

Yasmin Dean is an associate professor and Chair of the Department of Child Studies and Social WorkFaculty of Health, Community and Education — at Mount Royal University.

James Stauch is director of the Institute for Community Prosperity at Mount Royal University.

Cheryl Barnabe is an associate professor in the Departments of Medicine and Community Health Sciences - Cumming School of Medicine - at the University of Calgary (Calgary, Alberta, Canada).

Stephen Price is dean of the Faculty of Health, Community and Education at Mount Royal University.

Correspondence concerning this article should be addressed to Andrea Kennedy at akennedy@mtroyal.ca. 